\title{
PENGENALAN TEORI SERVICESCAPE DAN PENERAPANNYA DALAM DESAIN INTERIOR
}

\author{
Ulli Aulia Ruki \\ Jurusan Desain Interior, School of Design, BINUS University \\ Jl. K.H. Syahdan No. 9, Palmerah, Jakarta Barat 11480 \\ ulliaulia@gmail.com
}

\begin{abstract}
The reason of constructing the building facility is to facilitate users' activity and service. The article purpose is to introduce servicescape concept as a part of route that could be used to measure users' satisfaction level towards interior facility by giving additional value in selling goods and services in the building. Servicescape theory is one physical prove that could influence somebody's point of view about physical environment in a commercial facility. Some points discussed in servicescape are style, design, sign, space layout, function, and ambient condition. Method used is literature study from some books along with illustration analysis related to commercial facility interior. The expected result is to give point of view from servicescape theory that could be applied by an interior design in defining design concept especially related to commercial facility. The conclusion showed some points in servicescape theory that could be used to direct and deliver the designer to design concept decision that would satisfy facility interior users.
\end{abstract}

Keywords: servicescape, physical environment, commercial facility

\begin{abstract}
ABSTRAK
Latar belakang dibuatnya sebuah fasilitas gedung untuk dapat memfasilitasi aktivitas dan memberikan pelayanan kepada penggunanya. Tujuan artikel ini adalah mengenalkan konsep servicescape sebagai bagian dari landasan yang dapat digunakan untuk mengukur tingkat kepuasan penggunaan terhadap fasilitas interior dengan memberikan nilai tambah penjualan jasa ataupun barang yang di dalam gedung tersebut. Teori servicescape dapat menjadi salah bukti fisik yang dapat berpengaruh terhadap pandangan seseorang mengenai lingkungan fisik yang ada pada sebuah fasilitas komersial. Beberapa poin besar bahasan dari servicescape adalah gaya, desain, sign, space layout, fungsi dan ambient condition. Metode yang digunakan adalah studi pustaka dari beberapa buku serta analisa contoh dengan kaitannya terhadap interior fasilitas komersial. Hasil yang diharapkan adalah memberikan pandangan dari teori servicescape yang dapat diaplikasikan oleh seorang desainer interior dalam menentukan konsep desain terutama yang berkaitan dengan fasilitas komersial. Simpulan menunjukan beberapa poin yang ada pada teori servicescape dapat digunakan untuk mengarahkan dan mengantarkan para desainer kepada putusan konsep desain yang akan memuaskan pengguna interior fasilitas tersebut.
\end{abstract}

Kata kunci: servicescape, lingkungan fisik, fasilitas komersial 


\section{PENDAHULUAN}

Di dalam proses mendesain interior, ada baiknnya designer selalu memulai dengan cara melakukan survei dari kebutuhan manusia yang akan memakai fasilitas tersebut agar sesuai dengan kebutuhannya. Adanya sebuah fasilitas berawal dari suatu aktifitas yang dilakukan oleh manusiannya tersebut. Dengan adanya aktifitas maka akan ada fasilitas pendukung yang berguna untuk membuat pelaksanaanya tersebut berjalan dengan baik dan lancar. Ragam dari aktifitas seseorang pada sebuah fasilitas di gedung akan sangat bermacam pula, ini dikarenakan adanya job desk ataupun tanggung jawab seseorang kepada pekerjaannya ataupun jenis kegiatan yang sedang dilakukannya.

Sebagai contoh, Sekolah adalah suatu fasilitas yang disediakan untuk proses mengajar. Di sekolah tersebut telah terjadi proses interaksi antara pengajar dan murid yang berada dalam fasilitas ruangan yang telah disediakan. Kegiatan ini dapat difasilitasikan jika standard kebutuhannya terpenuhi dari kedua penggunannya. Tingkat kepuasan si pengguna mengenai fasilitas interior dapat diukur melalui respon yang dirasakan dari pengunjung ataupun karyawannya. Teori yang telah dikenalkan Bitner (1992) memberikan penjelasan bahwa adanya suatu saling keterkaitan antara suasana dengan lingkungan sekitar. Hal ini disebut dengan Servicescape atau yang juga biasa disebut dengan analisa dari respon secara keseluruahan mengenai pelayanan didalam lingkungan tersebut. Ruang lingkup servicescape dapat mengenali pentingnya dari lingkungan fisik sekitar dari karyawan dan juga kliennnya.

Halaman berikutnya akan memberikan informasi lebih banyak lagi mengenai servicescape dan juga bagaimana kombinasi lingkungan sekitar seperti ruangan, style desain simbol, layout, dan fungsi akan dapat memepengaruhi penilaian serta kebiasaan dari si pengguna fasilitas bangunan tersebut. Berikut adalah skema diagram tentang lingkup pembahasan yang ada pada jurnal ini.

\section{PEMBAHASAN}

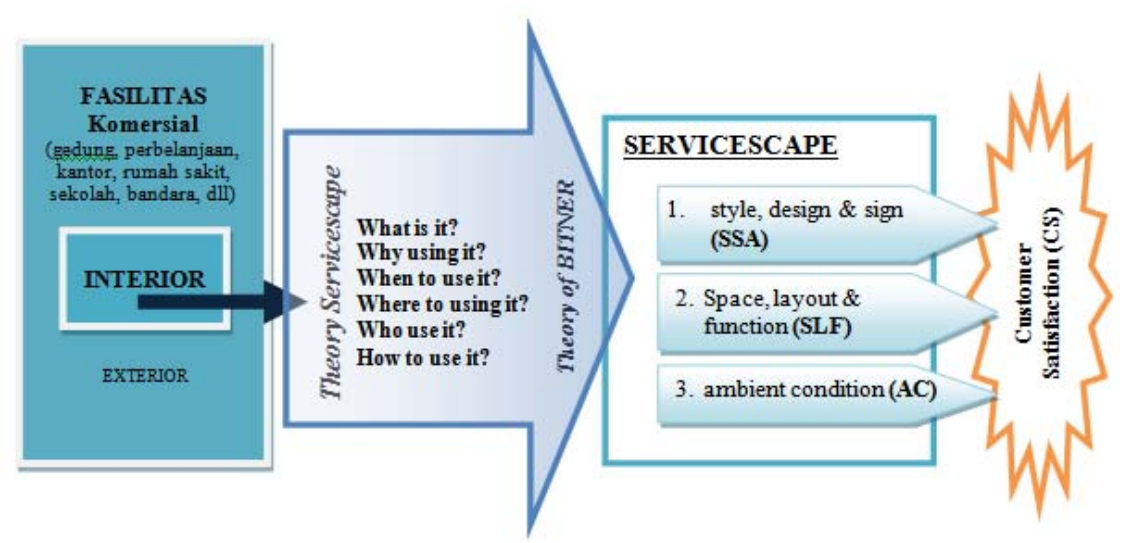

Gambar 1 Skema dari ruang lingkup pembahasan

\section{Penjelasan Mengenai Servicescape}

Definisi servicescape dijelaskan oleh Bitner (1992) sebagai lingkungan fisik yang didalamnnya mencakup pelayanan pada suatu fasilitas interior ataupun fasilitas di eksteriornya. Pelayanannya tersebut meliputi penilaian terhadap interior desain, desain exterior, simbol, tempat parkir, peralatan yang disediakan, denah layout, kualitas udara ataupun suhu udara yang ada pada fasilitas tersebut. 
Kata servicescape itu sendiri jarang digunakan di kesehariaan, namun kata ini sangat mudah dijelaskan dengan contoh kata seperti denah, kondisi lingkungan sekitar, temperature udara, kualitas udara, kebisingam, musik, gaya dekorasi dan lebih banyak lagi. Servicescape itu sendiri diilustrasikan dengan mengkombinasikan perasaan kognitif, emosional dan juga fisiologis. Ini artinnya dari beberapa indra perasa manusia dapat digunakan sebagai alat respon dan pemberi informasi mengenai ruangan ataupun lingkungan sekitar yang dirasakan oleh manusianya.

Beberapa penelitian mengatakan bahwa pengaturan lingkungan fisik dapat berpengaruh pada daya produktivitas dan motivasi kepada pekerjanya (Backer, 1981; Davis, 1984; Steele, 1986; Wineman, 1986; Sundstrom \& Altman, 1989; diliat pada Bitner, 1992). Sejak sebuah pelayanan adalah bersifat tidak dapat diraba, banyak dari klien hanya memperhatikan simbol lainnya yang bersifat lebih konkrit untuk dapat dievaluasi selama proses dan setelah proses pemakaiannya terjadi (Berry \& Clark, 1968; Shostack, 1977, dari Bitner, 1992).

\section{Elemen dari Servicescape}

Bitner (1992) telah mengemukakan mengenai beberapa element servicescape yang dapat dilihat dari Tabel 1.

Tabel 1 Elemen dari servicescape

\begin{tabular}{|c|c|c|c|c|}
\hline \multicolumn{2}{|c|}{ Servicescape } & \multirow{2}{*}{\begin{tabular}{l}
\multicolumn{1}{c}{ Element } \\
Kondisi lingkungan sekitar \\
(Ambience condition)
\end{tabular}} & \multicolumn{2}{|c|}{ Attribute } \\
\hline \multirow{3}{*}{ 竞 } & AC & & - Noise & - Température \\
\hline & SLF & $\begin{array}{l}\text { Ruang, Denah dan fungsi } \\
\text { (Space, layout, and function) }\end{array}$ & - furnishing & $\begin{array}{l}\text { - Layout } \\
\text { - Equipment }\end{array}$ \\
\hline & SSA & $\begin{array}{l}\text { Penunjuk, symbol, dan benda } \\
\text { artifak } \\
\text { (Signs, symbols and artifact) }\end{array}$ & $\begin{array}{l}\text { - Style of décor } \\
\text { - Personal artifact }\end{array}$ & $\begin{array}{l}\text { - Signage } \\
\text { - Etc }\end{array}$ \\
\hline
\end{tabular}

\section{Kondisi Lingkungan Sekitar (Ambient Conditions)}

Elemen yang pertama adalah sesuatu yang dapat dirasakan dari lingkungan kondisi sekitar. Manusia dapat memikirkan serta merespon dari pelayanan yang ada di tempat tersebut. Selain itu aspek ini mempunyai karateristik latar belakang dari lingkungan sekitar seperti temperatur, pencahayaan, kebisingan, kualitas udara, musik dan warna. Penelitian dari Milliman, 1982, 1986 menjelaskan bahwa pusat perbelanjaan tanpa musik dapat mempengaruhi kecenderungan pengunjungnnya untuk memutuskan berapa lama waktu yang akan dihabiskan pada saat mereka berbelanja.

Sebagai contoh banyak dari klien akan merasa sangat terganggu bila mereka harus datang ke suatu restaurant atau toko yang memasang musik terlalu bising. Musik juga dapat berdampak terhadap mood dari si pengunjung bila mereka melakukan aktivitas berbelanja atau makan diiringi dengan musik dengan perbandingan berbelanja atau makan yang suasannya sunyi tanpa ada suara apapun. 


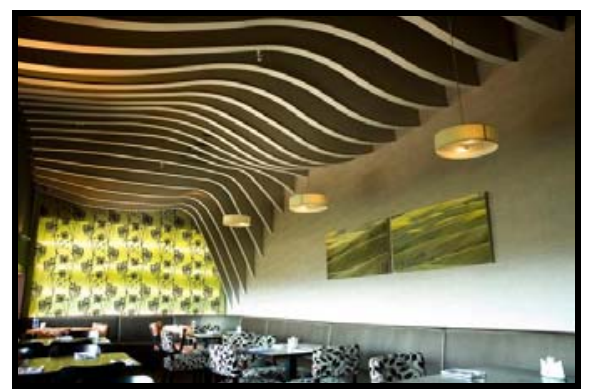

Gambar 1 Suasana interior restaurant

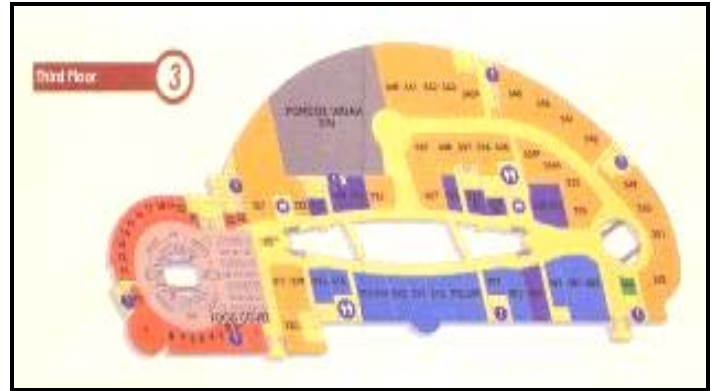

Gambar 2 Denah contoh pusat perbelanjaan

\section{Ruang, Denah dan Fungsinya (Spatial Layout and Functionality)}

Elemen kedua dari servicescape ini menjadi penting dikarenakan dapat memepengaruhi tingkah laku bekerja karyawan dan juga kebiasaan dari tingkah laku pengunjung pada gedung tersebut. Hal ini sangatkah penting diketahui terutama pada saat melakukan penempatan di sebuah fasilitas ritel.

Sebagai contoh, kebiasaan tingkah laku dari pengunjung sebuah mal biasannya akan lebih tertarik dengan toko yang letak posisinya lebih terlihat dari pintu ataupun lift. Hal ini dapat berdampak pada keputusan seseorang dalam berbelanja di toko yang mungkin posisinya tidak terlalu sulit dijangkau.

\section{Petunjuk, Simbol dan benda Artifak (Signs, Symbols and Artifacts)}

Elemen yang terakhir adalah yang paling sering dapat ditangkap oleh mata kita. Elemen simbol ini dirasakan penting untuk membantu pengunjung ataupun karyawan dalam mengkategorikan ruangan serta mengkomunikasikan secara simbolis. Untuk sebagian perusahaan beberapa benda penting akan diletakkan di bagian yang paling terlihat, karena perusahaan tersebut ingin mengenalkan filosofi perusahaan tersebut dan juga dapat menjadi ciri khas dari gedung yang dia gunakan.

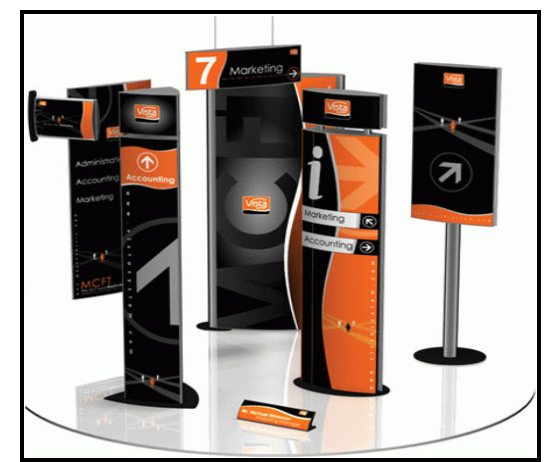

Gambar 3 Contoh petunjuk yang digunakan di interior

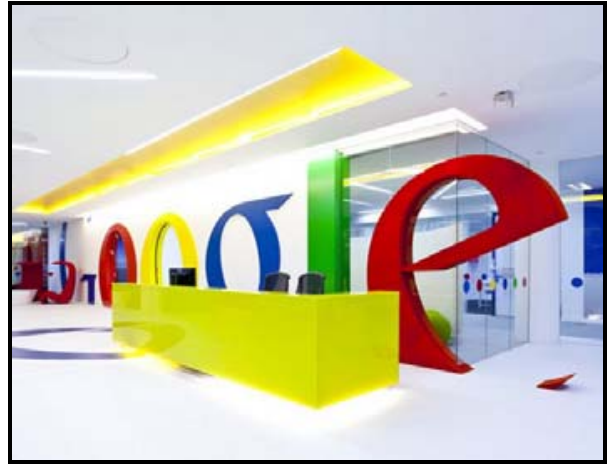

Gambar 4 Contoh simbol yang digunakan interior kantor Google

\section{Alasan Menggunakan Servicescape}

Beberapa pengarang dan penulis buku menyatakan tentang fasilitas fisik, contohnya adalah servicescape sebagai indikator kualitas (Ward et al., 1992; Baker et al., 1994; Baker: 1998; Aubertgamet and Cova, 1999; Baker et al., 2002, dalam Tuzovic, 2008). Servicescape secara umum digunakan untuk menjabarkan fasilitas fisik secara keseluruhan dalam sebuah perusahaan yang bergerak dalam bidang pelayanan. 
Hasil yang didapat menunjukan bahwa servicescape tidak hanya sebagai indikator untuk kualitas pelayanan yang hendak dicapai, tetapi juga mempengaruhi perhitungan dari ukuran dimensi karena secara langsung dan tidak langsung mempengaruhi hasil kualitas pelayanan. Untuk lebih mengerti mengenai alasan menggunakan servicescape, pada tabel 2 ini terdapat penjelasan mengenai fungsi dari servicescape dan keuntungannya.

Tabel 2 Role of servicescape

\begin{tabular}{|c|c|c|c|}
\hline & Peran dari servicescape & Penjelasan & $\begin{array}{l}\text { Contoh keuntungan } \\
\text { menggunakan servicescape }\end{array}$ \\
\hline & $\begin{array}{l}\text { Pembungkus } \\
\text { (Package) }\end{array}$ & $\begin{array}{l}\text { Elemen dari servicescape serupa dengan } \\
\text { indikator fisik lainnya dan pembungkus } \\
\text { ini berarti kemasan mereka terhadap } \\
\text { pelayanan dan komunikasi gambaran } \\
\text { luar kepada konsumen. }\end{array}$ & $\begin{array}{l}\text { Denah interior fasilitas ritel } \\
\text { seharusnya dibuat menarik agar } \\
\text { konsumen tertarik. }\end{array}$ \\
\hline 2. & $\begin{array}{l}\text { Memfasilitasikan } \\
\text { (Facilitator) }\end{array}$ & $\begin{array}{l}\text { Servicescape juga dapat berfungsi } \\
\text { sebagai fasilitator dalam membantu } \\
\text { performa seseorang dalam lingkungan, } \\
\text { seperti bagaimana mendesain sebuah } \\
\text { denah dan bagaimana denah dapat } \\
\text { meningkatkan efisiensi pergerakan dari } \\
\text { aktifitas pelayanan. }\end{array}$ & $\begin{array}{l}\text { Denah pusat perbelanjaan seharusnya } \\
\text { dibuat per grup berdasarkan produk } \\
\text { supaya konsumen mudah dalam } \\
\text { mencari } \\
\text {. }\end{array}$ \\
\hline 3. & $\begin{array}{l}\text { Mensosialisasikan } \\
\text { (Socializer) }\end{array}$ & $\begin{array}{l}\text { Desain dari servicescape membantu } \\
\text { sosialisasi bagi seluruh karyawan dan } \\
\text { konsumen yang dapat membantu } \\
\text { mengkomunikasikan kebiasaan dan } \\
\text { suatu hubungan. }\end{array}$ & $\begin{array}{l}\text { Kopi Starbucks mengambil tema } \\
\text { kedai kopi. Dimana konsumen dapat } \\
\text { menghabiskan waktu sosial mereka } \\
\text { dibandingkan dengan dating hanya } \\
\text { untuk membeli kopi lalu pergi. }\end{array}$ \\
\hline 4. & $\begin{array}{l}\text { Pembeda } \\
\text { (Differentiator) }\end{array}$ & $\begin{array}{l}\text { Desain dari fasilitas fisik dapat } \\
\text { dibedakan dari setiap persaingan dan } \\
\text { indikasi dari segmen pasar }\end{array}$ & $\begin{array}{l}\text { Di pusat perbelanjaan papan } \\
\text { penunjuk, warna digunakan dalam } \\
\text { dekorasi dan display dan tipe musik } \\
\text { bersenandung dari toko menandakan } \\
\text { segmen pasar. }\end{array}$ \\
\hline
\end{tabular}

Sumber: Zeithaml \& Bitner (2003), pp. 287-289

Secara umum Parasuraman, Zeithaml \& Berry (2003) menjelaskan pengertian dari servicescape sebagai alternatif indikator. Servicescape juga ditempatkan pada area komersial, digunakan untuk menghasilkan keuntungan (Zeithaml, Parasuraman \& Berry, 1990). Mengingat sebagai investasi, area ini harus sesuai dengan kegunaan tertentu dan kondisi simbol, ini menjadi alat bagi manajemen. Ini berarti servicescape dapat berguna bagi tujuan dan target marketing.

Dari jurnal services marketing oleh Wakefield \& Blodgett (1994), menyebutkan hasil keadaan servicescape juga dapat mempengaruhi kepada tingkah laku pengunjung terhadap waktu luangnya. Poin-poin penilaian yang bisa dijadikan alasan tepat dalam penerapan servicescape adalah: (1) kepuasan di dalam servicescape mempunyai dampak positif terhadap jangka waktu yang akan dihabiskan di tempat tersebut; (2) kepuasan dengan keadaan servicescape dapat berdampak positif terhadap keinginnan untuk kembalinya seseorang ke tempat tersebut; (3) akses yang mudah dan userfriendly pada denah juga dapat membawa pengaruh yang positif terhadap pengunjungnya; (4) bisa mendapatkan perhatian lebih banyak dari para pengunjung, bila kualitas estetika seperti mengecat ulang, mengganti gaya dekorasi disetiap musim ataupun di acara-acara khusus dapat menjadi daya tarik pada fasilitas tersebut. 


\section{Waktu yang Tepat dalam Menggunakan Servicescape}

Dalam penggunaan servicescape alangkah baiknya bila kita melihat jenis pelayanan yang diberikan oleh fasilitas umum tersebut. Penting atau tidaknya penerapan servicescape bisa menjadi suatu pokok persoalan dengan melihat waktu yang dihabiskan oleh pengunjung di dalam fasilitas tersebut. Tabel 3 merupakan penjelasan mengenai tipologi servicescape.

Tabel 3 Tipologi servicescape

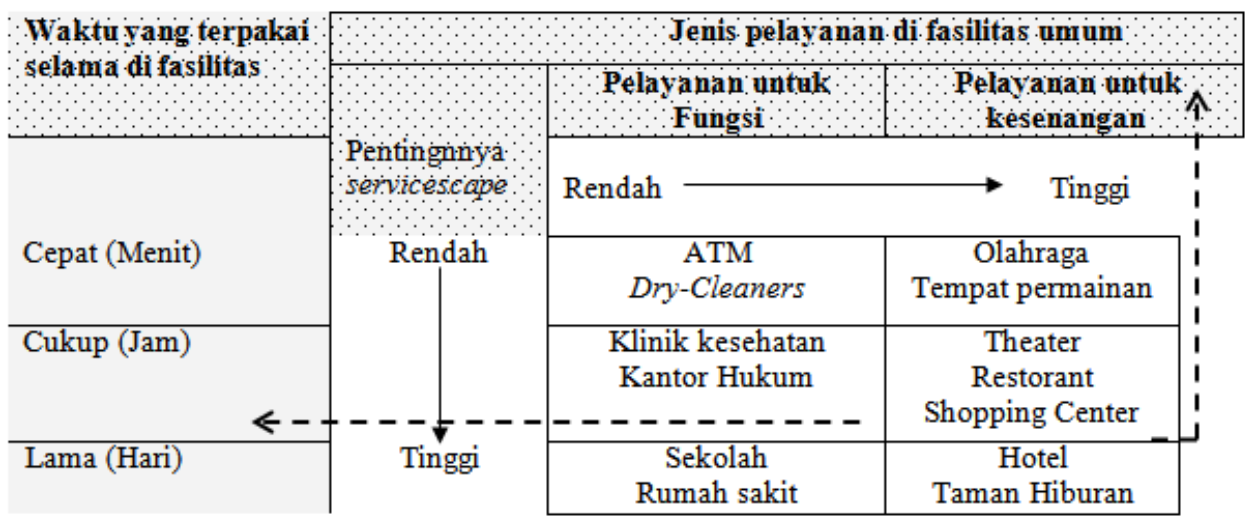

Sumber: Wakefield \& Blodgett, 1994

Tabel 3 menunjukan bahwa posisi sebuah fasilitas dapat diperhitungkan lama waktu yang dihabiskan sebanding dengan berapa pentingnya memperhatikan servicescape untuk dijadikan pokok persoalan. Semakin lama waktu yang akan dihabiskan ditemapat tersebut, maka servicescape akan dirasakan semakin penting.

Lebih jauh lagi, setiap tipe dari servicescape mempunyai jenis kompleks yang berbeda dalam pengaturannya. Servicescape akan mempunyai lebih sedikit proses, denah, peralatan, peningkatan geografi dan sedikit interaksi. Contoh lain yang hanya memerlukan sedikit servicescape adalah ATM, dry cleaner, dan tempat pusat pengisian ulang. Untuk tempat seperti ini biasanya akan dilakukan proses desain yang ringkas, dengan menggunakn denah yang hanya memerlukan sedikit peralatan didalamnnya.

Untuk contoh fasilitas komersial yang memerlukan tingkat yang lebih kompleks dengan interaksi yang dinamis adalah fasilitas resort bintang lima dan fasilitas bandara, dimana interaksi antara klien-karyawan, peralatan klien, peralatan-peralatan, karyawan-peralatan, serta karyawankaryawannya sangatlah bergerak dinamis. Dari sisi klien sangat membutuhkan element kenyamanan dan aman didalamnnya. Sedangkan penyedia jasa sangat membutuhkan suasana yang dapat mendukung daya produktivitas, kenyamanan operasional dan juga sikap ramah tamah.

\section{Pengaruh Servicescape terhadap Perilaku Pelanggan}

Pelanggan dan karyawan dapat merespon lingkungan fisik secara level emosional, kognitif dan pisikologis terhadap tingkah laku kebiasaan mereka, seperti dalam Zeithaml \& Bitner (1994). Respon tersebut meliputi lingkungan dengan kesadaran, emosi, psikologi, dan ragam respon dari setiap individu. 
Kesadaran akan servicescape akan berdampak pada seseorang hanya dengan merasakan dan melihat orang yang berdatangan serta barang yang dijual pada tempat tersebut. sebagai contoh dipusat perbelanjaan, banyak dari denahnya untuk lantai dasar dipergunakan sebagi area penjualan barang yang terkenal dengan kualiatas dan harga no satu dibandingkan dengan toko yang berada dilantai lainnya.

Penerimaan servicescape dapat dikatakan memepengaruhi emosi dan tingkah laku seorang pengunjung. Sebagai contoh: dengan dipasangnya warna yang terlalu cerah serta tata pencahayaan yang terlalu berlebihana akan mengakibatkan tingkah laku seseorang yang melihat karena adanya daya tarik yang menangkap reaksi dari mata seseorang.

Penerimaan akan servicescape akan mempengaruhi cara psikologi seseorang. Sebagai contoh adalah area yang terlalu ramai pada suatu restauran dengan adannya musik yang keras, asap rokok yang pekat, akan membuat seseorang yang tidak merokok merasa terganggu dan menyebabkan rasa tidak nyaman ataupun sakit.

Tujuan dari servicescape ini sangatlah beragam di setiap responnya, dan ini akan selalu berbeda dari satu orang ke orang yang lain. Karena setiap personal seseorang berbeda, maka dapat menyebabkan keputusan respon yang berbeda pula. Sebagai contoh ada beberapa klien yang merasa tidak punya pilihan untuk memilih tempat lain dikarenakan fasilitas yang ada ternyata lebih dekat dengan posisi rumahnnya namun ada juga yang memilih fasilitas yang lebih jauh dari posisi rumahnnya dikarenakan fasilitasnnya menawarkan yang lebih baik.

\section{Penerapan Servicescape dalam Desain Interior}

Telah dijelaskan sebelummnya bahwa Booms \& Bitner (1981) telah mendefinisikan servicescape sebagai perekat antara penjual dan pembeli yang saling berinteraksi dengan mengkombinasikan. Kebutuhan barang dan kinerja sebuah fasilitas ataupun dengan mengkomunikasikan dari semua jenis pelayanan yang ada (Booms \& Bitner, 1981). Begitupun juga saat menerapkan sebuah konsep interior, alangkah baiknnya seorang interior desain memperhatikan terlebih dahulu jenis pelayanan yang ditawarkan pada fasilitas tersebut. karena dengan menerapkan servicescape pada interior yang sesuai dengan jenis pelayanannya maka desain interiornnya dapat menjadi nilai jual pada suatu area terbaru.

Sebagai contoh, dengan membuat atau merenovasi area ruangan yang didesain untuk memenuhi aktifitas bermain anak-anak di sebuah gedung mall bisa menjadi sangat 'happening place' di Jakarta karena ternyata desain dan ketepatan pemilihan servicescape yang digunakan dalam interiornnya menjadikannya nilai tersendiri bagi pengunjung yang datang. Servicescape itu sendiri dapat dikenal menjadi 3 bagian besar untuk sebuah pelayanan.

\section{Servicescape untuk Pelayanan yang Melayani Diri Sendiri (A Self Service)}

Jenis pelayanan self services adalah jenis aktifitas yang dilakukan dengan terbatas. Atau biasannya hanya interaksi antara mesin dan juga klien. Namun terkadang aktivitas ini juga tetap memerlukan pemantauan dari karyawannya. Contoh servicescape dengan jenis pelayanan ini biasannya terdapat pada ATM dan tempat-tempat olahraga. Fasilitas ATM saat ini menjadi pilihan yang peraktis, karena untuk aktifitas mengambil uang bisa dilakukan selama 24 jam tanpa harus bergantung dengan jam kerja karyawannya 


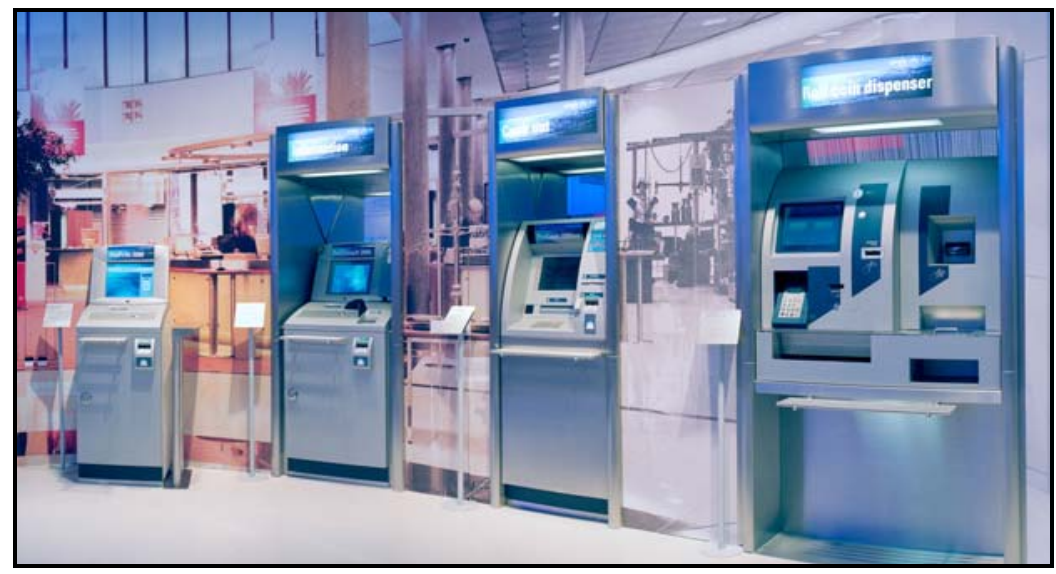

Gambar 5 Suasana interior pada ATM center

Dari Gambar 5 dapat dilihat bahwa interaksi yang terjadi dibatasi hanya antara mesin dan 1 orang, mesin ini mempunyai besaran yang telah didesain sesuai dengan ergonomic manusia dalam keadaan berdiri. Desain yang digunakan tidak terlalu rumit agar mesin ATM tetap menjadi fokusnya, untuk tata letak mesinnya dibuat berdampingan karena adannya kecenderungan garis antrian orang yang akan bergantian untuk menggunakannya. Pencahayaan yang digunakan adalah general dan spotlight yang focus pada mesin ATMnya. Sedangkan penghawaan yang digunakan adalah AC general dengan memperhatikan kebutuhan menjaga suhu ruang dan suhu ATM agar tidak terlalu panas.

Contoh lain servicescape yang digunakan jenis servicescape adalah tempat olah raga atau gym. Pelayanan dari fasilitas tersebut adalah menyediakan peralatan untuk berolahraga, untuk itu strateginnya adalah menyediakan peralatan olah raga yang terkini agar dapat tetap mengikuti keinginan pasar dan memeneuhi target dari pengunjungnnya.

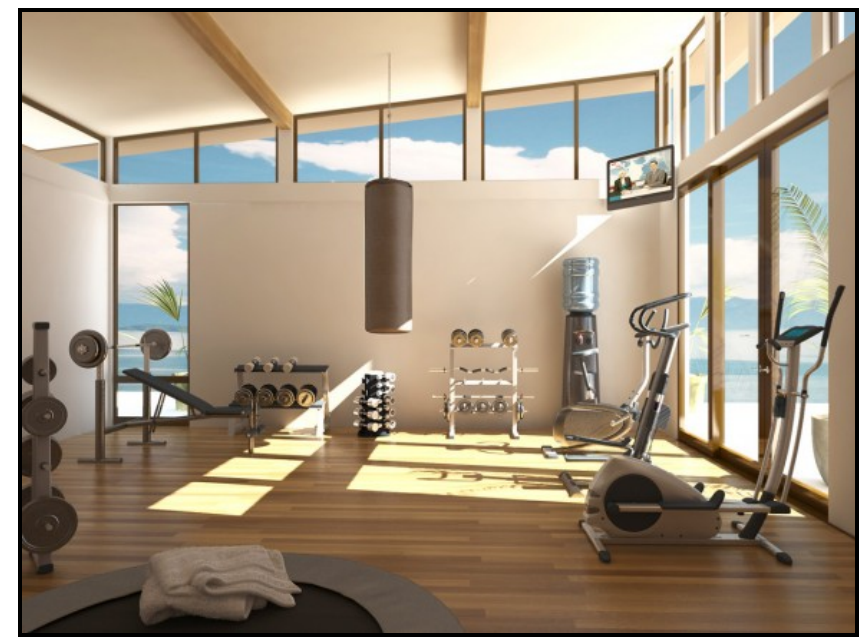

Gambar 6 Suasana interior tempat olahraga

Dapat dilihat dari gambar interior (Gambar 6), sebaiknnya peletakan peralatannya di bedakan berdasarkan kategori fungsi dari setiap peralatannya. Untuk menjaga suasana ruang yang kondusif, pencahayaan dapat dikombinasikan dengan cahaya alami dari luar, agar pengguna masih merasakan suasana alam. Untuk penghawaan sebaiknnya direcanakan secara matang agar tetap membuat pengunjung nyaman tanpa merasa kepanasan, kedinginan ataupun mencium bau yang tidak sedap karena badan cenderung akan mengeluarkan keringat lebih banyak.

\section{Servicescape untuk Pelayanan Antar Perorangan (An interpersonal)}


Bila suatu bidang jasa dilakukan dengan berinteraksi langsung antara klien dan penyedia jasa seperti rumah sakit, sekolah, bank dan hotel, maka servicescape harus dangat diperhatikan desainnya yang lebih menarik, memuaskan dan dapat memfasilitasikan segala aktiftas dari segala pihak agar menjadikan suasana kondusif diantara kedua belah pihak.

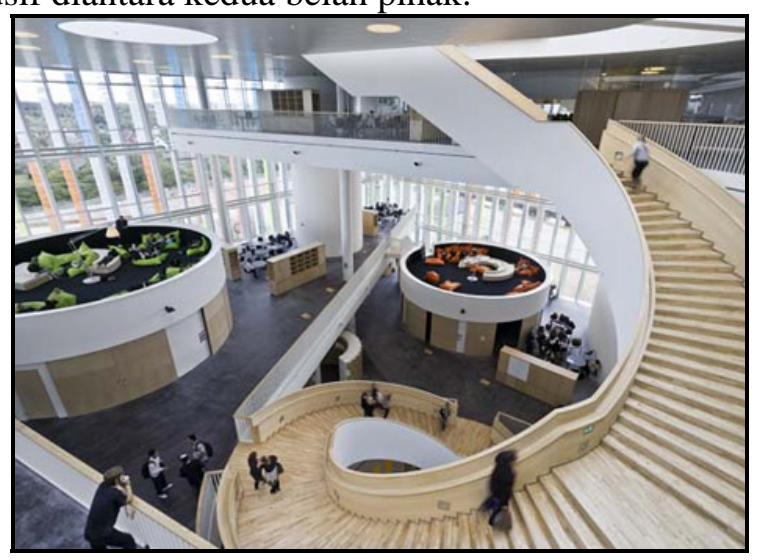

Gambar 7 Suasana interior hall di universitas

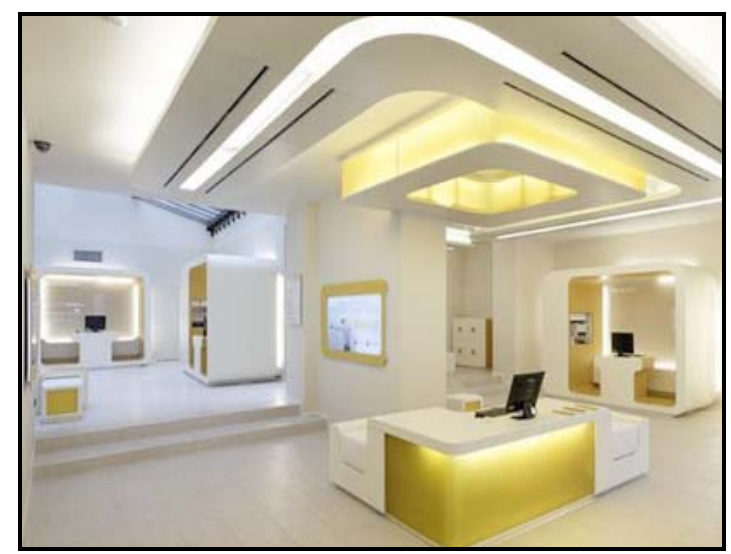

Gambar 8 Suasana interior bank

Dari kedua gambar desain interior pada Gambar 7 dan 8, dapat terlihat adannya pengelompokan area untuk mendukung aktifitas yang fokus atara penyedia jasa dan penerima jasa. Dari pemilihan desain juga masih tetap dipilihkan desain yang tidak terlalu rumit, ini dimaksudkan untuk memudahkan operasional gedung tersebut. Dilihat dari segi pencahayaannya disusun secara general agar merata disetiap ruangan namun tetap diberikan kesan estetisnnya untuk memanjakan mata pengunjung. Untuk pemilihan warna pada interior ada baiknnya dipilihkan warna netral dan dipilihkan beberapa warna aksen berdasarkan filisofi perusahaannya.

\section{Servicescape untuk Pelayanan Jarak Jauh (A Remote)}

Beberapa penerapan interior yang tidak banyak membutuhkan penilaian kliennya adalah jenis pelayanannya dilakukan dari jarak jauh, contohnnya adalah call center sebuah perusahaan telekomunikasi, perusahaan asuransi dan jenis perusahaan lainnya yang melayani jasa dari belakang meja kantor. Akan tetapi penilaian servicescape ini tetap diperlukan untuk menjaga nilai motivasi dan semangat kerja dari karyawannya. Servicescape jenis ini sangat perlu memperhatikan nilai ergonomis furniturennya karena karyawannya bekerja 8-10 jam dalam sehari (lihat gambar 9. Untuk suasana interior back office). Servicescape untuk kantor seperti ini harus dapat memenuhi kepuasan dari karyawannya, agar mereka merasa diperhatikan, merasa di berikan kebutuhannya, dan juga merasa bahwa kantornnya nyaman seperti ruamh kedua mereka, sehingga akan berpengaruh positif kepada semangat kerja karyawan. 


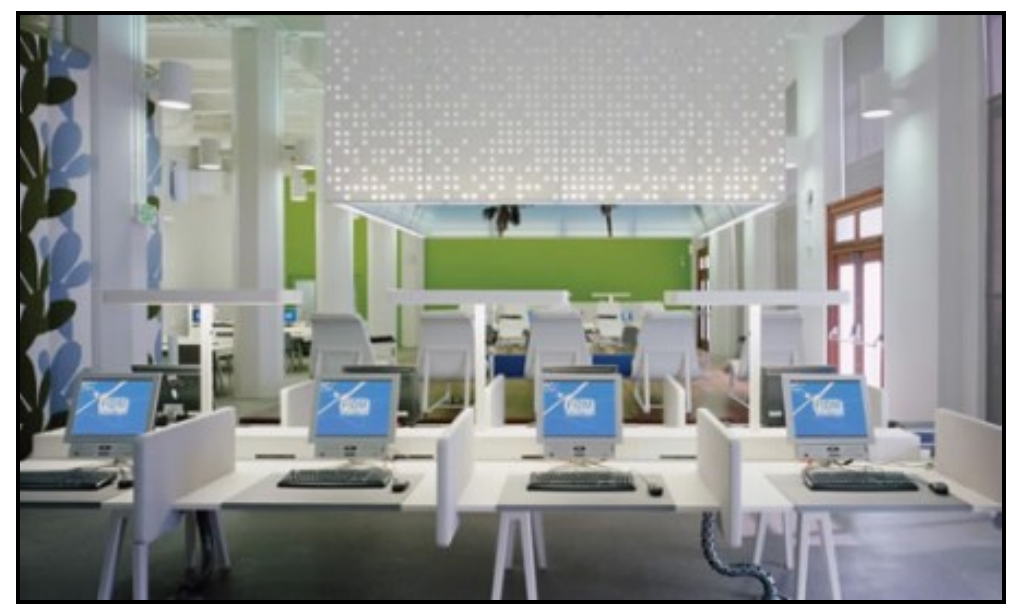

Gambar 9 Suasana interior back office

Pada Gambar 9, terdapat suasana interior kantor yang dibuat transparan tanpa penyekat. Ini dimaksudkan untuk memudahkan supervisi dan operasionalnya dilakukan secara tepat oleh karyawan yang jumlahnnya mungkin lebih dari 100 orang. Selain itu dengan dibuatnya system kantor yang terbuka seperti ini, dapat dirasakan oleh karyawannya bahwa mereka adalah satu tim dan tidak adannya pembatas antara divisi satu dan divisi lainnya.

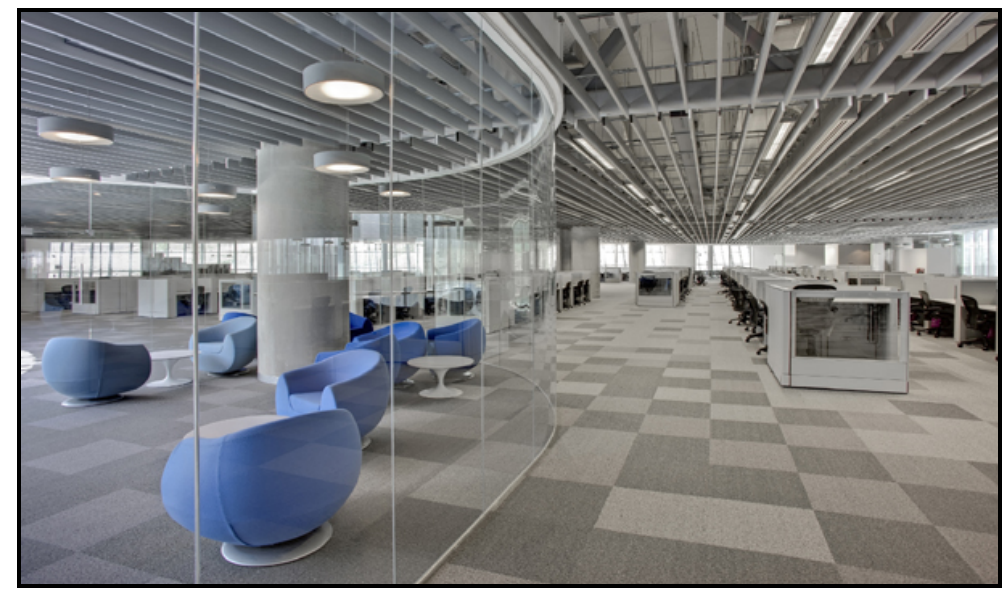

Gambar 10 Suasana interior kantor remote center

\section{PENUTUP}

Teori servicescape ini banyak di bahas dalam bidang marketing, namun tidak ada salahnnya membahasnya sebagai bagian dari penambah ilmu yang bisa di tambahkan untuk desainer interior sebagai perluasan wawasan dan untuk mengeksplorasi nilai tambah yang bisa diberikan pada karyanya. Dari pembahasan yang ada di atas, dapat dikatakan bahwa servicescape adalah suatu respon yang bisa dijadikan penelitian awal sebelum menentukan keputusan desain untuk diterapkan pada saat membangun terutama fasilitas umum yang bergerak dibidang komersial. Dampak dari keputusan yang kurang tepat di dalam interior akan berdampak pada jangka panjang nilai investasi suatu penjualan baik jasa dan barang. Beberapa poin besar yang dapat dilakukan adalah memperhatikan element servicescape pada saat mendesain, seperti style, design \& sign (SSA), Space, layout \& function (SLF), ambient condition (AC). 
Contoh kesalahan kecil yang ditemukan pada fasilitas interior adalah hal seperti pemasangan simbol petunjuk yang tidak baik letaknnya dan tidak mudah terlihat, selain itu tidak adanya konsep matang untuk pemasangan sound system dan alat elektronik pendukung lainnya seperti cctv ataupun alat pengamanan lainnya, sehingga akan adanya bongkar pasang yang menambah waktu dan biaya tambahan. Contoh kesalahan yang dapat berdampak besar adalah dalam penentuan bentuk denah serta pembagian dan peletakan ruang interior, hal ini mempengaruhi perilaku karyawan dan juga pengunjungnnya serta nilai efesiensi dan efektifitas kerja yang jangka panjangnnya bila dihitung dengan nilai nominal akan berdampak luas.

Bisa dibayangkan nilai investasi sebuah gedung yang akan dibangun dapat menjadi kurang laku dipasaran, dikarena pengambilan keputusan yang salah ataupun kurangnnya penilaian strategi pada awal melakukan penelitian investasi bisnisnnya. Seberapa positif kah nilai servicescape untuk diterapkan seorang desainer interior dalam menghasilkan karyannya, hal ini harus diadakan kembali penelitian yang lebih mendalam dengan data kualitatif. Bila memang berdampak positif maka dapat di teliti lebih jauh lagi dampak dalam jangka pendek ataupun jangka lebih panjang.

\section{DAFTAR PUSTAKA}

Bitner, M. (1992). Servicescape: the impact of physical surroundings on customer and employess. Journal of marketing.

Booms, B. H., \& Bitner, M. J. (1981). Marketing strategies and organization structures for service firms. In J. H. Donelly \& W. R. George (Eds.), Marketing of services. Chicago: American Marketing Association.

Booty, F. (2003). Facility management handbook. UK: Lexix Nexix Butterworths.

Finlinson, J. (n.d.). How physical surrounding can influence the behavior of both costumer and employees. Marriot school of management. Diakses Juni 2011, dari http://www.slideshare.net/ahmad1957/servicescapes-presentation

Ghanghas, M. (n.d.). Roles resvicescape in marketing of servicesi. Diakses Juni 2011, dari http://www.123oye.com/job-articles/advertising-sales-management/servicescape.htm

Lin, Y, I. (2004). Evaluating a servicescape: The effect of cognition and emotion. Journal Hospitality management, 23. Diakses Juni 2011, dari http://www.ba.aegean.gr/m.sigala/paperservicescape.pdf

Sulek, J. M., Lind, M. R., \& Maruchek, A. S. (1995). The impact of customer services intervention and facility design on firm performance. Mangement science, 41 no 11.

Tuzovic, S. (2008). Investigating the concept of potential quality: An exploratory study in the real estate industry. Managing Service Quality, Vol. 18 No. 3, 2008, pp. 255-271.

Wakefield, K. L., \& Blodgett, J. G. (1994). The important servicescape in leisure services settings. Journal Services marketing, Vol. 8 Iss: 3, pp. 66-76.

Zeithaml, V. A., \& Bitner, M. J. (2003). Services marketing integrating customer focus across the firm. New York: McGraw-Hill.

Zeithaml, V. A., Parasuraman, A., \& Berry, L. L. (1990). Delivering quality service: Balancing customer perceptions and expectations. New York: The Free Press. 